\title{
Deciding the Rank of Factors Affecting Abu Dhabi Oil \& Gas Industry
}

\author{
Fatima Taher Al Mansoori ${ }^{1 *}$, Ismail Abdul Rahman ${ }^{2}$, Rozilah Kasim ${ }^{3}$ \\ ${ }^{1,3}$ Faculty of Technology Management and Business, \\ Universiti Tun Hussein Onn Malaysia (UTHM), Batu Pahat, Johor, 86400 Parit Raja, MALAYSIA \\ ${ }^{2}$ Faculty of Civil Engineering and Built Environment, \\ Universiti Tun Hussein Onn Malaysia (UTHM), Batu Pahat, Johor, 86400 Parit Raja, MALAYSIA \\ ${ }^{3}$ Faculty of Business and Technology Management, \\ Universiti Tun Hussein Onn Malaysia (UTHM), Batu Pahat, Johor, 86400 Parit Raja, MALAYSIA \\ *Corresponding Author
}

DOI: https://doi.org/10.30880/ijscet.2020.11.02.015

Received 30 July 2020; Accepted 30 August 2020; Available online 02 September 2020

\begin{abstract}
This paper presents the ranking of factors affecting Abu Dhabi oil \& gas industry which involved 100 valid responses. The respondents were requested to rate 25 identified factors which are clustered into five groups using 5-point Likert scale with scale 5 for extremely significant to scale 1 for not significant. The data collected from the survey was analysed descriptively using mean score index and standard deviation. The findings of the ranking analysis show the five most significant factors affecting the performance in the oil \& gas industry are Rewards and recognition, Low employee turnover, Effective behaviour, Assuring job security, and Effective support system. These findings are useful for further investigation on the factors affecting performance in oil \& gas industry.
\end{abstract}

Keywords: Oil \& gas industry, affect factors, performance

\section{Introduction}

United Arab Emirate (UAE) depends considerably on oil\& gas resources with the purpose of assistance its economy since 1971 and become one of the top ten producer of petroleum in the world (EIA, 2017). Since then Abu Dhabi National Oil Company (ADNOC) was formed to achieve all features of the oil \& gas industry of the emirate. In 1990, the ADNOC refinery has established together with several other companies were started to manage, operate, and more advance the oil \& gas sector in Abu Dhabi. According to Statistics Centre Abu Dhabi (SCAD), the oil \& gas sector participated about 55\% to total GDP in 2013. Also, GDP of Abu Dhabi is projected to have increased by around $4.8 \%$ that the oil \& gas sector was contributed a part of this grow. In 2016, the UAE produced 3.7 million barrel per day (bpd) of petroleum and crude oil 2.9 million bpd with the residual 0.8 million bpd non-crude liquids. Beyond the OPEC countries, the UAE embraces the fourth-largest oil producing after Saudi Arabia, Iran, and Iraq (Mills, 2016). By 2020 mostly by utilizing Enhanced Oil Recovery (EOR) methods for a number of its current oil fields, the UAE plans to develop crude oil production to 3.5 million bpd (EIA, 2017). ADNOC operates above 12 subsidiaries and organisation in Abu Dhabi with varieties operation from discovery, production, storage, refining and distribution, into the improvement of an extensive variety of petrochemical productions (ADNOC, 2016). Taking into account that Abu Dhabi takes over $96 \%$ of the oil in UAE, ADNOC is reflected the main moving power in the UAE oil market and 
Supreme Petroleum Council (SPC) as the major body for forming oil policy. Abu Dhabi vision 2030 lunched plans to more improve the oil \& gas industry, whereas simultaneously expand the economy to decrease its dependence on this area. On top of remarkable development can be recognized partly to the significant of employees' performance and organizational performance in this industry.

Abu Dhabi, being the heart of UAE, is one of the main oil \& gas exporters in the world. Considering its financial performance in 2015 and 2016, the company did not perform that well and had to reduce its number of human resources to save its cost. Around five thousand jobs were cut down in 2016 to sustain the Abu Dhabi National Oil Company. Abu Dhabi oil \& gas industry suffered financial crisis in 2015 to 2016, the leadership of the companies were replaced with new directors, thousands of staff members were cut down because the company believed that operations could run effectively with low cost. By reducing the cost, the company was financially able to motivate the remaining employees. The company started to regain its position and met its targets in 2017. ADNOC is focused on petrochemical production to lead the oil \& gas sector. The company's profit for the year 2018 was 2128 million AED. The company's total revenue increased from 19756 million AED to 22893 million AED. As for shareholder wealth, a dividend of 117600 AED per share was disbursed. These figures highlight the improved performance of the company. Al Harbi et al. (2018) believed that the ADNOC reflects the overall performance of the industry. Currently, the industry developed rapidly and capturing new markets as it was positively influenced by the mentioned factors (Al Harbi et al., 2018). Literature review indicated that the importance of leadership in the context of oil \& gas sectors on the performance of organizations has not been explored especially in UAE. The same argument to further study on the subject of organisational culture and its impact on increases or worsens company performance. Also found it is necessary to investigate effect of training factors and also on employees' job satisfaction toward organizational performance is being neglected in the oil \& gas sectors especially for Abu Dhabi situation. Thus, the paper presents the study to uncover factors that affecting oil \& gas company performance focussing the region of Abu Dhabi, UAE.

\section{Oil and gas company performance}

According to Al-Damen (2017), the performance of oil \& gas industry is the development of the industry to generate more revenue, reducing more costs, improving operational and exploring activities, expanding markets, and contributing to the national economy. Al-Damen (2017) also stated that internal factors impact the company's performance more than the external factors. As a company is a group of people who work together towards a similar objective so it is essential that the people must work collectively and in the right direction. For Harbour (2017), an organizational performance is reflected in three different areas which are financial position, market share, and shareholder value. These three areas are the substituents of organization, hence, organizational performance can be measured by measuring the performance of these three areas. Financial performance of the company could be measured by observing the difference in the company's revenue and expenditures over any selected period. These can be checked through financial statements of the company. On the other hand, the market performance is measured by analysing the performance of any specific product in the market. It assesses if the product market share has risen or increased sales. McDavid et al. (2018) believed that the shareholder value is the exact measuring tool for organizational performance. Shareholder value is the value that the company provides to its owners or investors.

According to Cameron (2015), the organizational performance is dependent on the following factors; leadership, organizational culture, job satisfaction, motivation and employee training. Leadership involves directing employees towards the organizational objective and monitoring and controlling their progress. Organizational culture provides a sound environment that helps them to work smoothly and collectively. One must be satisfied with the work he does; it is job satisfaction that could keep an employee within the organization for longer time. It has been observed that motivated employees yield better results and devise better strategies. Hence, employees must be kept motivated using monetary or non-monetary forms. A well-trained employee can work efficiently by saving time and cost of the organization. Therefore, the overall performance of an organization is dependent on these five factors and the current research is aimed at assessing the impact of these factors. From the current factors, organizational culture and leadership are more important. According to Cameron (2015), a sound organizational culture can motivate the employee itself along with keeping him within the organization for long term. Companies with good organizational environment retain employees longer and have low employees' turnover rate. Similarly, leadership is the key to every organizational success. Employees move towards the vision that their leader shows them. Hence, the five factors namely leadership, organizational culture, job satisfaction, motivation and employee training can impact the performance of the organization. These factors influence employees to increase revenue, decrease cost and expenses, work efficiently, reach out to more customers and work collectively towards organizational objective. The lists of affect factors to company performance are as in Table 1. 
Table 1- List of factors affecting company performance

\begin{tabular}{|c|c|c|c|}
\hline Group & Code & Factor & Explanation of the factor \\
\hline \multirow{5}{*}{ Leadership } & L1 & $\begin{array}{l}\text { Effective } \\
\text { behaviour }\end{array}$ & $\begin{array}{l}\text { Good and effective leadership behaviour is important for } \\
\text { improving the overall performance of the organization. }\end{array}$ \\
\hline & $\mathbf{L} 2$ & Empowerment & $\begin{array}{l}\text { Improving empowerment of employees and subordinates' } \\
\text { results in impacting the overall performance of your } \\
\text { organization. }\end{array}$ \\
\hline & $\mathbf{L 3}$ & $\begin{array}{l}\text { Good } \\
\text { governance }\end{array}$ & $\begin{array}{l}\text { Assuring good governance at organizational level lead towards } \\
\text { improving performance of organization. }\end{array}$ \\
\hline & L4 & $\begin{array}{l}\text { Effective } \\
\text { participation }\end{array}$ & $\begin{array}{l}\text { Effective participation of leaders results in attainment of } \\
\text { organizational strategic objective in an effective and efficient } \\
\text { way. }\end{array}$ \\
\hline & L5 & $\begin{array}{l}\text { Helping } \\
\text { subordinate }\end{array}$ & $\begin{array}{l}\text { Leadership at your organization helps subordinate to achieve } \\
\text { success at individual and organizational level. }\end{array}$ \\
\hline \multirow{5}{*}{ Training } & T1 & $\begin{array}{l}\text { Regular } \\
\text { coaching }\end{array}$ & $\begin{array}{l}\text { Regular coaching opportunities results in improving the work } \\
\text { performance. }\end{array}$ \\
\hline & $\mathbf{T} 2$ & $\begin{array}{l}\text { Up-skilling } \\
\text { employee }\end{array}$ & $\begin{array}{l}\text { Up-skilling employees' skills and expertise on regular basis } \\
\text { results in achieving effective organizational performance. }\end{array}$ \\
\hline & T3 & $\begin{array}{l}\text { Knowledge } \\
\text { sharing }\end{array}$ & $\begin{array}{l}\text { Training allows high level of knowledge sharing leading } \\
\text { towards high level of organizational learning. }\end{array}$ \\
\hline & T4 & $\begin{array}{l}\text { learning } \\
\text { opportunities }\end{array}$ & $\begin{array}{l}\text { Providing employees with learning opportunities improve their } \\
\text { capabilities. }\end{array}$ \\
\hline & T5 & $\begin{array}{l}\text { Training } \\
\text { regularly }\end{array}$ & $\begin{array}{l}\text { Training and development sessions on regular basis are source } \\
\text { of achieving competitive position. }\end{array}$ \\
\hline \multirow{5}{*}{ Motivation } & M1 & $\begin{array}{l}\text { Supporting } \\
\text { employees }\end{array}$ & $\begin{array}{l}\text { Supporting employees by top management results in } \\
\text { motivating employees. }\end{array}$ \\
\hline & M2 & $\begin{array}{l}\text { Job } \\
\text { enrichment }\end{array}$ & $\begin{array}{l}\text { Job enrichment is source of engaging employees with } \\
\text { organization for a long term. }\end{array}$ \\
\hline & M3 & $\begin{array}{l}\text { Rewards and } \\
\text { recognition }\end{array}$ & $\begin{array}{l}\text { Rewards and recognition lead towards increasing overall } \\
\text { employee performance. }\end{array}$ \\
\hline & M4 & $\begin{array}{l}\text { Low employee } \\
\text { turnover }\end{array}$ & $\begin{array}{l}\text { Assuring low level of employee turnover is positive for } \\
\text { organizational performance. }\end{array}$ \\
\hline & M5 & $\begin{array}{l}\text { Motivating } \\
\text { employee }\end{array}$ & $\begin{array}{l}\text { Employees with high level of motivation lead towards } \\
\text { successful achievement of organizational objectives. }\end{array}$ \\
\hline \multirow{5}{*}{$\begin{array}{l}\text { Organizational } \\
\text { culture }\end{array}$} & C1 & $\begin{array}{l}\text { Apply total } \\
\text { quality } \\
\text { management }\end{array}$ & $\begin{array}{l}\text { Implementing total quality management methods results in } \\
\text { improving operational performance of organization. }\end{array}$ \\
\hline & $\mathrm{C} 2$ & $\begin{array}{l}\text { Collaborative } \\
\text { shared value }\end{array}$ & $\begin{array}{l}\text { Enhanced and collaborative shared value results in improving } \\
\text { productive of teams and employees. }\end{array}$ \\
\hline & $\mathrm{C3}$ & $\begin{array}{l}\text { Creativity and } \\
\text { innovation }\end{array}$ & $\begin{array}{l}\text { Integrating creativity and innovation in an organizational } \\
\text { environment assures improved level of performance. }\end{array}$ \\
\hline & C4 & Reward policy & $\begin{array}{l}\text { Effective reward management policies in an organization } \\
\text { assures long term commitment of employees. }\end{array}$ \\
\hline & C5 & $\begin{array}{l}\text { Supportive } \\
\text { culture }\end{array}$ & $\begin{array}{l}\text { Supportive organizational cultural environment assures } \\
\text { dedicated output of employees. }\end{array}$ \\
\hline \multirow{5}{*}{ Job satisfaction } & $\mathbf{J 1}$ & $\begin{array}{l}\text { Competitive } \\
\text { salary }\end{array}$ & $\begin{array}{l}\text { Competitive compensation and salary levels increasing overall } \\
\text { satisfaction of employees with organization. }\end{array}$ \\
\hline & $\mathbf{J} 2$ & $\begin{array}{l}\text { Effective } \\
\text { support } \\
\text { system }\end{array}$ & $\begin{array}{l}\text { Effective support from supervisors improve the performance of } \\
\text { employees. }\end{array}$ \\
\hline & $\mathbf{J 3}$ & $\begin{array}{l}\text { Positive } \\
\text { workplace } \\
\text { environment }\end{array}$ & $\begin{array}{l}\text { Positive and supportive workplace environment is source of } \\
\text { satisfying employees. }\end{array}$ \\
\hline & $\mathrm{J4}$ & $\begin{array}{l}\text { Assuring job } \\
\text { security }\end{array}$ & $\begin{array}{l}\text { Assuring job security results in dedication and hard work from } \\
\text { employees. }\end{array}$ \\
\hline & J5 & $\begin{array}{l}\text { Increase } \\
\text { employee } \\
\text { satisfaction }\end{array}$ & $\begin{array}{l}\text { Increased level of employees' job satisfaction results in } \\
\text { improved organizational performance. }\end{array}$ \\
\hline
\end{tabular}




\section{Data collection}

Data was collected through questionnaire survey of the targeted 100 respondents of senior employees of oil \& gas industry who work as site managers, quality control surveyors, project managers, engineers and official staffs throughout ADNOC. Since the survey was conducted through face to face with the respondents and hence the response rate for the survey is $100 \%$.

Table 2 - Respondents' demography

\begin{tabular}{lcc}
\hline Qualification & Frequency & Percentage \\
\hline Diploma & 76 & $76 \%$ \\
Bachelor Degree & 14 & $14 \%$ \\
Master Degree & 2 & $2 \%$ \\
PhD & 1 & $1 \%$ \\
Others & 7 & $7 \%$ \\
\hline Total & $\mathbf{1 0 0}$ & $\mathbf{1 0 0 \%}$ \\
\hline Job status & Frequency & Percentage \\
\hline Project director & 6 & $6 \%$ \\
General manager & 72 & $72 \%$ \\
Project manager & 10 & $10 \%$ \\
Senior officers & 12 & $12 \%$ \\
\hline Total & $\mathbf{1 0 0}$ & $\mathbf{1 0 0 \%}$ \\
\hline Working experience in oil \& gas company & Frequency & Percentage \\
\hline 0-5 years & 52 & $52 \%$ \\
6-10 years & 6 & $6 \%$ \\
11-15 years & 30 & $30 \%$ \\
16-20 years & 5 & $5 \%$ \\
21-25 years & 7 & $7 \%$ \\
More than 25 years & 0 & $0 \%$ \\
\hline Total & $\mathbf{1 0 0}$ & $\mathbf{1 0 0 \%}$ \\
\hline
\end{tabular}

Table 2 indicates that 76 of the respondents (76\%) are having Diploma qualifications, 14 of them have Bachelor's Degree, two of them have Master's Degree, only one of them have $\mathrm{PhD}$, while 7 respondents are having Other qualification. Since majority of the respondents are having a good level of knowledge, this could assist the reliability in answering the questionnaire. According to job status it is noticeable that most of the respondents are general managers measured 72 respondents with a percentage $72 \%$ of the total number of participants. Thus in the third category of the demography item, majority of the respondents have been working for 0 to 5 years (52\%), while $30 \%$ had 11 to 15 years ef in oil \& gas industry. Before the collected data can be used for further analysis, the data was checked using the reliability test. The test parameter to check the internal consistency of the data is through Cronbach's alpha value, range from 0 and 1 where 1 means that the data is highly reliable and valid while value 0 means vice versa (Tavakol $\&$ Dennick, 2011; Adeyemi, Martin \& Kasim, 2017).

Table 3 - Reliability test

\begin{tabular}{cc}
\hline \multicolumn{2}{c}{ Table 3 - Reliability test } \\
\hline \multicolumn{2}{c}{ Reliability Statistics } \\
\hline Cronbach's alpha & N of items \\
0.798 & 27 \\
\hline
\end{tabular}

Table 3 shows the results of reliability test of 27 items, company's performance and the factors affecting oil \& gas industry using the indicator of Cronbach's alpha value. The results indicate that the collected data are having Cronbach's alpha values of almost 0.8. This means that the data are reliable as according to Yahaya et al. (2007) which stated that alpha value in the range 0.8 to 1 is considered highly reliable and valid. Thus, the internal consistency of questionnaire items for this study is considered acceptable.

\section{Ranking of factors affecting company performance}

Data collected from Part C of the questionnaire survey are on the level of importance for each of the 25 factors given by 100 respondents. The 5-points Likert's scale provided in the questionnaire were 1- Not Strong, 2- Less Strong, 3 -Neutral, 4- Strong, and 5-Very Strong. Based on this data, mean score of each item was determined and then the factors were ranked according their scores. However, there are some factors having same mean score and resulting tied ranks. To resolve this, standard deviation score of each factor is considered for adjusting these ranks as depicts in Table 4. 
Table 4 - Ranking of factors affecting performance

\begin{tabular}{clcccc}
\hline Code & \multicolumn{1}{c}{ Factor } & Mean score & Rank & Std. deviation & Adjusted rank \\
\hline M3 & Rewards and recognition & 3.61 & 1 & 1.188 & 1 \\
M4 & Low employee turnover & 3.57 & 2 & 1.066 & 2 \\
L1 & Effective behaviour & 3.54 & 3 & 1.058 & 3 \\
J4 & Assuring job security & 3.54 & 3 & 1.123 & 4 \\
J2 & Effective support system & 3.53 & 4 & 1.159 & 5 \\
T4 & learning opportunities & 3.5 & 5 & 1.106 & 6 \\
L5 & Helping subordinate & 3.48 & 6 & 1.132 & 7 \\
J5 & Increase employee satisfaction & 3.45 & 7 & 1.058 & 8 \\
T2 & Up-skilling employee & 3.45 & 7 & 1.158 & 9 \\
C4 & Reward policy & 3.45 & 7 & 1.192 & 10 \\
M5 & Motivating employee & 3.43 & 8 & 1.057 & 11 \\
T5 & Training regularly & 3.42 & 9 & 1.065 & 12 \\
C5 & Supportive culture & 3.4 & 10 & 1.198 & 13 \\
T1 & Regular coaching & 3.39 & 11 & 1.230 & 14 \\
C1 & Apply total quality management & 3.36 & 12 & 1.097 & 15 \\
J1 & Competitive salary & 3.36 & 12 & 1.185 & 16 \\
L2 & Empowerment & 3.35 & 13 & 1.140 & 17 \\
L4 & Effective participation & 3.35 & 13 & 1.175 & 18 \\
C2 & Collaborative shared value & 3.31 & 14 & 1.107 & 19 \\
M1 & Supporting employees & 3.31 & 14 & 1.152 & 20 \\
M2 & Job enrichment & 3.3 & 15 & 1.185 & 21 \\
J3 & Positive workplace environment & 3.27 & 16 & 1.109 & 22 \\
T3 & Knowledge sharing & 3.26 & 17 & 1.097 & 23 \\
L3 & Good governance & 3.24 & 19 & 1.138 & 24 \\
C3 & Creativity and innovation & 3.25 & 18 & 1.167 & 25 \\
\hline & & & & &
\end{tabular}

Table 4 indicates that most factors scores are 3.24 and above, overall average is 3.40 , and this means most of them are important and affecting oil \& gas industry according to the respondents. Referring to previous studies on ranking of factors, these studies selected 5 to 10 of the most significant factors for further elaboration (Emam et al., 2015; Sambasivan \& Soon, 2007; Fugar \& Agyakwah-Baah, 2010). Hence this study elaborated five most significant factors which are Rewards and recognition, Low employee turnover, Effective behaviour, Assuring job security and Effective support system. These factors are elaborated in accordance with the other research works to show its degree of importance affecting oil \& gas industry as follow;

\section{i. Rewards and recognition}

Rewards and recognition is the most important factors to motivate employee. Management should always explore the best reward and on how to recognize the employee's achievement because employees will see it as sign of appreciation of their contribution. Tulgan (2009) was found that as the intrinsic and extrinsic rewards provided by the organization increased more than the expectations of an employee and that effect on organization performance

ii. Low employee turnover

Low employee turnover is the second important motivation factor in handling project. Organizational growth and performance affected by organizational commitment, satisfaction, employee effectiveness, low turnover intent, trust, effective leadership and overall employee performance (Schlechter, 2005). This factor can increase or decrease employee turnover depending on organization policy towered the employee.

\section{iii. Effective behaviour}

The third most important factor leadership is effective. Role of leader in an organization is critically linked with performance of organization. Organizations can be more effective and flexible when significant investments are made by organization on employees and optimal fit level between information, work, technology, and people should be achieved by the organization because motivation, commitment and employees' abilities can be enhanced and performance of organization can also be positively affected by these types of practices (Huselid, 1995). 


\section{iv. Assuring job security}

Job security is forth most important factor resulted from the survey. Every employee looks for a modicum of security and safety of his or her employment and this has been widely recognized as one of the key factors impacting employee commitment and performance. Loss of job security leads to several other issues such as low motivation, low commitment and in some cases, even depression and other physical ailment (Sanyal, \& Hisam, 2018), according to that job security effecting on performance due low motivation and low commitment and depression.

\section{v. Effective support system}

The fifth most important factor is effective support system where it requires holistic and systemic support for staff and that effective support depended on the creation of organizational cultures that were characterized by high expectations, high support and high challenge and more over the supervisors as leaders who are close to employees (Ruiz-Palomino et al., 2013; Sakiru et al., 2013). Thus, effective support from them effect directly on their performance.

\section{Conclusion}

This paper has presented the assessment of factors affecting Abu Dhabi oil \& gas industry which involved 100 valid responses. The collected data was analysed descriptively using mean score index and standard deviation. The findings of the ranking analysis shows the five most significant cause factors affecting the performance in the oil \& gas industry are Rewards and recognition, Low employee turnover, Effective behaviour, Assuring job security, and Effective support system. These findings are useful for further investigating the relationship between cause and effect factors.

\section{Acknowledgement}

The authors would like to thank University Tun Hussein Onn Malaysia for supporting this study.

\section{References}

Adeyemi, A., Martin, D, \& Kasim, R. (2017). The relevance of lean thinking to sustainable improvement of public office buildings in Nigeria, Journal of Engineering and Applied Sciences 12 96), pp.1365-11376

Al Harbi, M., Viswanathan, R., \& Al Shamsi, M. (2018). Management of Change: A Journey towards Simplifying the MOC Process in ADNOC Onshore. In Abu Dhabi International Petroleum Exhibition \& Conference. Society of Petroleum Engineers

Al-Damen, R. A. (2017). The Impact of Total Quality Management on organizational performance Case of Jordan Oil Petroleum Company. International Journal of Business and Social Science, 8(1), 192-202

Cameron, K. (2015). Organizational effectiveness. Wiley Encyclopedia of Management, 1-4

EIA, U. (2017). Country Analysis Brief: United Arab Emirates

Emam, H., Farrell, P., \& Abdelaal, M. (2015, September). Causes of delay on infrastructure projects in Qatar. In Proceedings of the 31st Annual ARCOM Conference, Lincoln, UK, Association of Researchers in Construction Management, Nottingham, UK (pp. 773-782)

Fugar, F. D., \& Agyakwah-Baah, A. B. (2010). Delays in building construction projects in Ghana. Construction Economics and Building, 10(1-2), 103-116

Harbour, J. L. (2017). The basics of performance measurement. Productivity Press

Huselid, M. A. (1995). The impact of human resource management practices on turnover, productivity, and corporate financial performance. Academy of management journal, 38(3), 635-672

McDavid, J. C., Huse, I., \& Hawthorn, L. R. (2018). Program evaluation and performance measurement: An introduction to practice. Sage Publications

Mills, R. (2016). Risky routes: energy transit in the Middle East. Qatar: Brookings Doha Center

Ruiz-Palomino, P., Martínez-Cañas, R., \& Fontrodona, J. (2013). Ethical culture and employee outcomes: The mediating role of person-organization fit. Journal of Business Ethics, 116(1), 173-188 
Sakiru, O. K., D'Silva, J. L., Othman, J., DaudSilong, A., \& Busayo, A. T. (2013). Leadership styles and job satisfaction among employees in small and medium enterprises. International Journal of Business and Management, $8(13), 34$

Sambasivan, M., \& Soon, Y. W. (2007). Causes and effects of delays in Malaysian construction industry. International Journal of project management, 25(5), 517-526

Sanyal, S., \& Hisam, M. W. (2018). The impact of teamwork on work performance of employees: A study of faculty members in Dhofar University. IOSR Journal of Business and Management, 20(3), 15-22

Schlechter, A. F. (2005). The influence of transformational leadership, emotional intelligence, trust, meaning and intention to quit on organisational citizenship behaviour (Doctoral dissertation, Stellenbosch: University of Stellenbosch)

Tavakol, M. \& Dennick. R. (2011). Making sense of cronbach's alpha. International Journal of Medical Education, 2, 53-55

Tulgan, B. (2009). Not everyone gets a trophy: How to manage generation Y. John Wiley \& Sons

Yahaya, A., Hashim, S., Ramli, J., Boon, Y., \& Hamdan, A.R. (2007). Mengusai Penyelidikan dalam Pendidikan. Kuala Lumpur: PTS Publication 